\title{
Performance of electrokinetic treatment of fine-grained problematic soils
}

\author{
Abiola Ayopo Abiodun* and Zalihe Nalbantoglu \\ Department of Civil Engineering, Eastern Mediterranean University, Famagusta, North Cyprus via Mersin 10 Turkey. \\ * Corresponding Author : abiola.abiodun@cc.emu.edu.tr
}

Submitted : 10/10/2019

Revised :22/12/2020

Accepted :07/02/2021

\begin{abstract}
Electrokinetic (EK) treatment is an innovative, cost-effective in situ ground modification technology. The EK treatment uses a combination of low-voltage direct-current, electrodes, and ionic solutions across problematic soil to improve the ground conditions. This study aims to model the effect of changing electrode length $\left(l_{\mathrm{e}}\right)$ on the performance of the EK treatment on the engineering properties of fine-grained problematic soils. The consideration of the changing electrode lengths $\left(l_{e}\right)$, varying soil depths $\left(d_{s}\right)$, and lengthwise anode to cathode distances $\left(d_{A \leftrightarrow E}\right)$, in the soil block samples, is in the form of the laboratory model test tank. The significant performance of the experimental tests was with changing electrode lengths of $0.251_{\mathrm{e}}(7.5 \mathrm{~cm}), 0.501_{\mathrm{e}}(15.0 \mathrm{~cm}), 0.751_{\mathrm{e}}(22.5 \mathrm{~cm})$, and $1.01_{\mathrm{e}}$ $(30.0 \mathrm{~cm})$. The study analyzed the test data obtained from the Atterberg limit and one-dimensional swelling tests at different extraction points of the EK treated soils in the test tanks. Furthermore, the study carefully analyzed the effect of changing electrode length $\left(l_{\mathrm{e}}\right)$ on the performance of the EK treatment. The results of the Design of Experiment (DOE) model analysis revealed that the effect of changing electrode length $\left(l_{\mathrm{e}}\right)$ on the plasticity index (PI), and swelling potential (SP) of the EK treated soils, was significant. For a specific soil depth $\left(d_{s}\right)$, the electrode lengths $\left(1_{e}\right)$ of $0.501_{\mathrm{e}}$ and $0.751_{\mathrm{e}}$ were significantly effective in reducing the PI, and the SP of the EK treated soils. Unlike other studies in the literature, the use of DOE analysis in the present study enabled the detection of the significant input factors and their interactive effects on the PI and the SP, thus, enabling the practicing engineers to navigate accurate design models for large in situ applications.
\end{abstract}

Keywords: Design of experiment; Electrode length; Electrokinetic treatment; Plasticity index; Problematic soils; Soil depth; Swelling potential.

\section{INTRODUCTION}

Problematic soils are challenging to geotechnical engineers due to their undesirable properties such as low strength, high plasticity, and high-volume instability (Jeyakanthan et al. 2011; Abiola and Nalbantoglu 2016; Azhar et al. 2017). The EK treatment is uniquely an innovative chemical soil stabilization technique to mitigate the unsatisfactory properties of fine-grained soils using different ionic solutions. It is a simple and cost-time effective method (Mosavat et al. 2012; Malekzadeh et al. 2016). It is a non-disturbance method with no detrimental effects to foundation structures adjacent to or founded in insitu or exsitu treated soils (Mosavat et al. 2014; Abiola and Nalbantoglu 2018; Liu et al. 2018). Many key factors control the optimal performance of the EK treatment of soils. 
These typically include the appropriate selection of the materials used and the interactive effects of the types and concentrations of ionic solutions. Also, they are precisely the electrode types and the arrays, the treatment procedures and the specific duration, the potential direction of flow, and the required magnitude of electrical charges (Abdullah et al. 2010; Jayasekera, 2015; Liu et al. 2017).

Since interactions of EK materials will produce different effects on the properties of EK treated soils. It is essential to examine the most suitable selection of the material types and configurations of a laboratory-scale model before large scale in situ applications. Previous studies in the literature examined the performance of EK treatment employing the conventional experimental methods to evaluate the outcome of the preliminary results (Liaki et al. 2010; Jeyakanthan et al. 2011; Gingine and Shah 2013; Mosavat et al. 2013; Moayedi et al. 2014a; Moayedi et al. 2014b; Askin et al. 2016; Feijoo et al. 2017a; Mohanty et al. 2017; Mu'azu et al. 2017; Alrubaye et al. 2018; Azhar et al. 2018). Such traditional EK treatment methods can only evaluate the effect of each input factor with no keen interactions with other input factors.

The conventional method could not establish a significant effect among the selected independent factors to navigate accurate design models for large scale in situ applications (Bezerra et al. 2008; Myers et al. 2009; Mohammed et al. 2013; Feijoo et al. 2017b). There is a need for the selection of suitable input factors to monitor, analyze, and examine robust design models for effective application for soil improvement (Anderson and Whitcomb 2005).

Although vast EK treatment of soils has proven to be effective to stabilize the plasticity and swelling potential of problematic soils (Wu et al. 2016; Panjaitan and Andi, 2017; Malekzadeh and Sivakugan, 2017), a few studies (Rittirong et al. 2008; Cho et al. 2012; Askin and Turer, 2016) have considered the effect of ionic solutions with changing electrode length $\left(l_{e}\right)$, soil depth $\left(d_{s}\right)$, and anode to cathode distance $\left(\mathrm{d}_{\mathrm{A} \leftrightarrow \mathrm{E}}\right)$. The present study aims to establish the significant electrode length $\left(l_{\mathrm{e}}\right)$ dimension required to achieve better plasticity index (PI) and swelling potential (SP) in the EK treated soils. In the present study, the tests were performed with the input factors: changing electrode lengths $\left(l_{\mathrm{e}}\right)$, soil depths $\left(\mathrm{d}_{\mathrm{s}}\right)$, and anode to cathode distances $\left(\mathrm{d}_{\mathrm{A} \leftrightarrow \mathrm{E}}\right)$ and were analyzed for their interaction effect.

The interaction effects between the specified input factors were examined using a statistical software program, Design-Expert version 11.0, Stat-Ease, Inc. using a response surface methodology, RSM. The RSM in the design of experiment (DOE) critically evaluated if the selected input factors were significant and established a relationship suitable to achieve better soil improvement for EK treated soils. Also, the use of ANOVA analyses, interactive RSM plots, and predictive models helped evaluate the significant factors influencing the response by varying the input factors simultaneously. In this study, key factors such as ionic solution concentration, temperature, and voltage gradient were kept constant during the EK treatment of soil. The selected input factors were coded in the software program at a low, medium, and high level, to observe their effects on the responses after the EK treatment of soil. The analyses of the input factors influencing the performance of the EK treatment aim to formulate the relationship between the input factors and the targeted soil properties, so that suitable electrode dimensions for EK treatment of the given soil could be established. These analyses are vital to reduce the cost and time and effectively improve the quality of the performance of EK treatment of soil along the depths and the lengthwise distances in problematic soils.

\section{EXPERIMENTAL MATERIALS}

\section{Soil}

The soil used in the present study has a plastic limit (PI) of 33\%, and a liquid limit (LL) of $60 \%$. The plasticity index (PI) of the soil is $27 \%$. According to the unified soil classification system (USCS), the soil was classified as a 
highly plastic silty clay. Based on Peck et al. (1974), the soil with a plasticity index between $20 \%$ to $55 \%$ was considered to have a high swelling potential. Table 1 gives the index properties of the soil used in the study. The soil block dimension was $40 \mathrm{~cm} \times 15 \mathrm{~cm}$ x $30 \mathrm{~cm}$ for the length, width, and height, respectively.

Table 1. Physical and index properties of the soil blocks.

\begin{tabular}{|c|c|}
\hline Soil index properties & Values \\
\hline Clay size fraction, $<0.002 \mathrm{~mm}(\%)^{\mathrm{a}}$ & 61 \\
\hline Silt size fraction, $0.002-0.074 \mathrm{~mm}(\%)^{\mathrm{a}}$ & 36 \\
\hline Sand size fraction, $>0.074 \mathrm{~mm}(\%)^{\mathrm{a}}$ & 3 \\
\hline Specific gravity, Gs ${ }^{b}$ & 2.75 \\
\hline Liquid limit, LL $(\%)^{\mathrm{c}}$ & 60 \\
\hline Plastic limit, PL $(\%)^{\mathrm{c}}$ & 33 \\
\hline Plasticity index, PI $(\%)^{\mathrm{c}}$ & 27 \\
\hline Swelling potential, SP $(\%)^{\mathrm{d}}$ & 1.62 \\
\hline Bulk density of the soil, $\rho_{b}\left(\mathrm{~g} / \mathrm{cm}^{3}\right)$ & 1.94 \\
\hline Water content of the soil, $w(\%)$ & 48 \\
\hline Unified soil classification system $^{\mathrm{e}}$ & $\mathrm{CH}$ \\
\hline \multicolumn{2}{|c|}{$\begin{array}{l}\text { a According to ASTM (1998) D422, }{ }^{\mathrm{b}} \text { According to ASTM (2006) D854. }{ }^{\mathrm{c}} \text { According to ASTM } \\
\text { (2000a) D4318, }{ }^{\mathrm{d}} \text { According to ASTM D } 4546 .{ }^{\mathrm{e}} \text { According to ASTM (2000b) D2487-00 } \\
\text { (Unified Soil Classification System). }\end{array}$} \\
\hline
\end{tabular}

\section{Ionic Solutions}

The selected ionic solutions were calcium chloride dihydrate $\left(\mathrm{CaCl}_{2} \cdot 2 \mathrm{H}_{2} \mathrm{O}\right)$ and sodium carbonate anhydrous $\left(\mathrm{Na}_{2} \mathrm{CO}_{3}\right)$. They are nontoxic, noncorrosive, and highly soluble in water. They are inexpensive and environmentally safe. Table 2 presents the chemical and physical properties of the ionic solutions used in the present study. 
Table 2. Chemical and physical properties of the electrolytes.

\begin{tabular}{|c|c|c|c|}
\hline Properties & $\begin{array}{c}\text { Calcium Chloride at } \\
\mathbf{1 . 0} \mathbf{M}\end{array}$ & $\begin{array}{c}\text { Sodium Carbonate at } \\
\mathbf{1 . 0} \mathbf{M}\end{array}$ & Deionized water \\
\hline Molecular formula & $\mathrm{CaCl}_{2} .2 \mathrm{H}_{2} \mathrm{O}$ & $\mathrm{Na}_{2} \mathrm{CO}_{3}$ & $\mathrm{H}_{2} \mathrm{O}$ \\
\hline Molar mass, $\mathrm{g} / \mathrm{mol}$ & 110.98 & 105.99 & 18.02 \\
\hline Density, $\mathrm{g} / \mathrm{cm}^{3}$ at $20^{\circ} \mathrm{C}$ & 1.85 & 2.15 & 1.00 \\
\hline Toxicity & Non-corrosive & Non-corrosive & Non-toxic \\
\hline $\mathrm{pH}$ & 8.65 & 11.75 & 7.00 \\
\hline Electrical conductivity, $\mathrm{E}_{\mathrm{c}}(\mathrm{S} / \mathrm{m})$ & 10.87 & 18.58 & 0.055 \\
\hline Solubility in water, $s(\mathrm{~g} / \mathrm{L})$ at $20^{\circ} \mathrm{C}$ & 147.10 & 105.99 & --- \\
\hline
\end{tabular}

\section{Test Tank}

Figure 1 shows the schematic diagram of the properly sealed, transparent test tank used in the study. It is made up of glass sheets having a thickness of $5 \mathrm{~mm}$ with given dimensions.

\section{Legends}

1. Anolyte chamber

2. Anode

3. Extraction points

4. Soil chamber

5. Catholyte chamber

6. Cathode

7. Perforated holes

8. Test tank

9. Electric wire

10. Power supply device

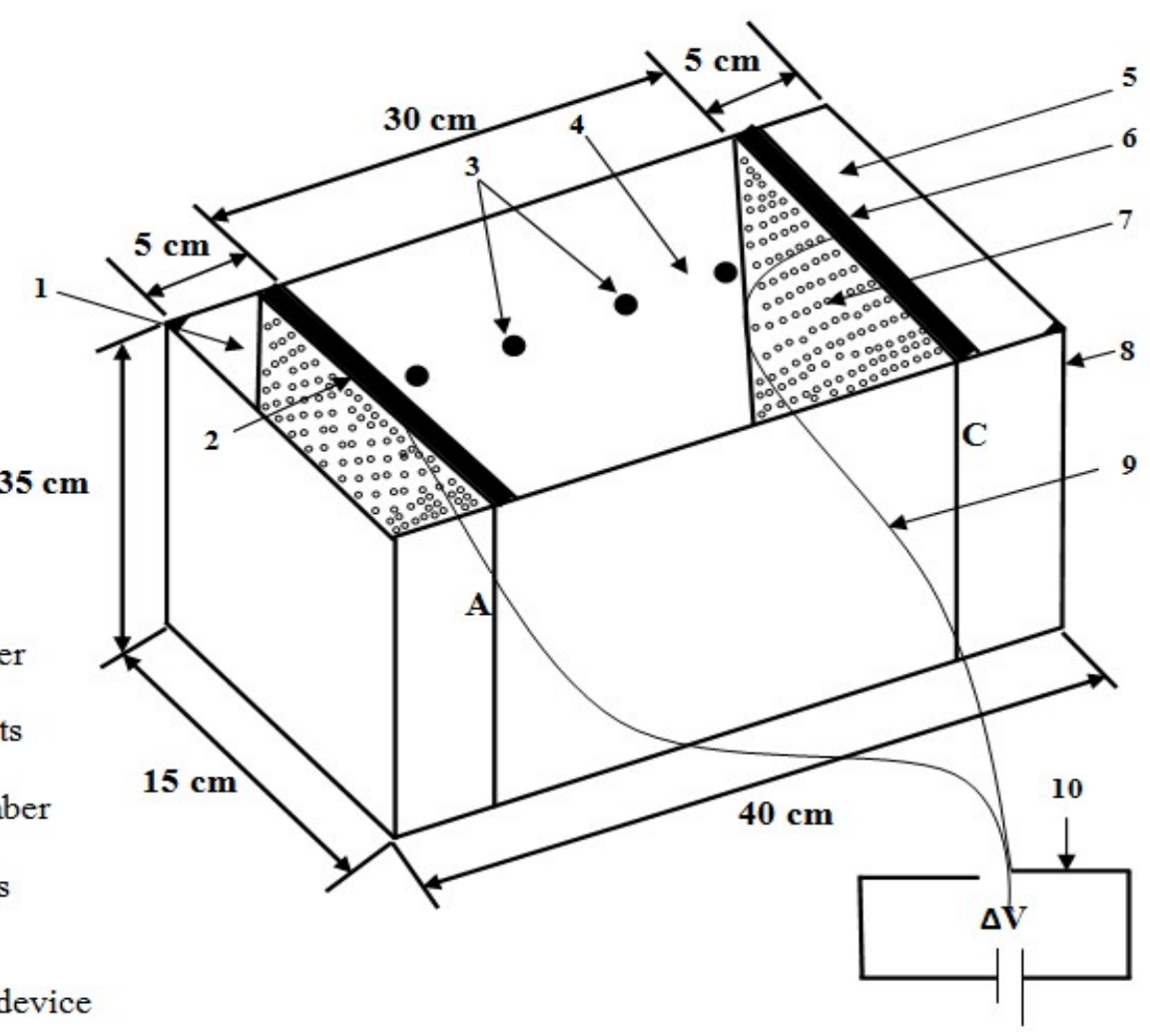

Figure 1. Schematic diagram of the electrokinetic test tank setup. 
The glass tank is nonconductive to avoid electrocution (short-circuiting). Its transparency makes it easy to monitor the level of water or ionic solutions in their chambers, fluid leakage, electroosmotic flow, and changes in the physicochemical properties of the EK treated soils.

\section{Electrodes}

The aluminum and mild-steel served as the anode and cathode plates, respectively. The electrodes used have dimensions of $0.15 \mathrm{~cm}, 15 \mathrm{~cm}$, and $30 \mathrm{~cm}$ in thickness, width, and height, respectively. The electrode plates were perforated to ease the flow of ionic solutions from their chambers into the soil blocks during the EK treatment of soil. Figure 2 shows four different dimensions of electrode lengths $\left(1_{\mathrm{e}}\right)$ of $7.5 \mathrm{~cm}\left(0.251_{\mathrm{e}}\right), 15 \mathrm{~cm}\left(0.501_{\mathrm{e}}\right), 22.5 \mathrm{~cm}\left(0.751_{\mathrm{e}}\right)$, and $30 \mathrm{~cm}\left(1.01_{\mathrm{e}}\right)$ used in the test tanks along the soil depths $\left(\mathrm{d}_{\mathrm{s}}\right)$, and anode to cathode distances $\left(\mathrm{d}_{\mathrm{A} \leftrightarrow \mathrm{E}}\right)$.

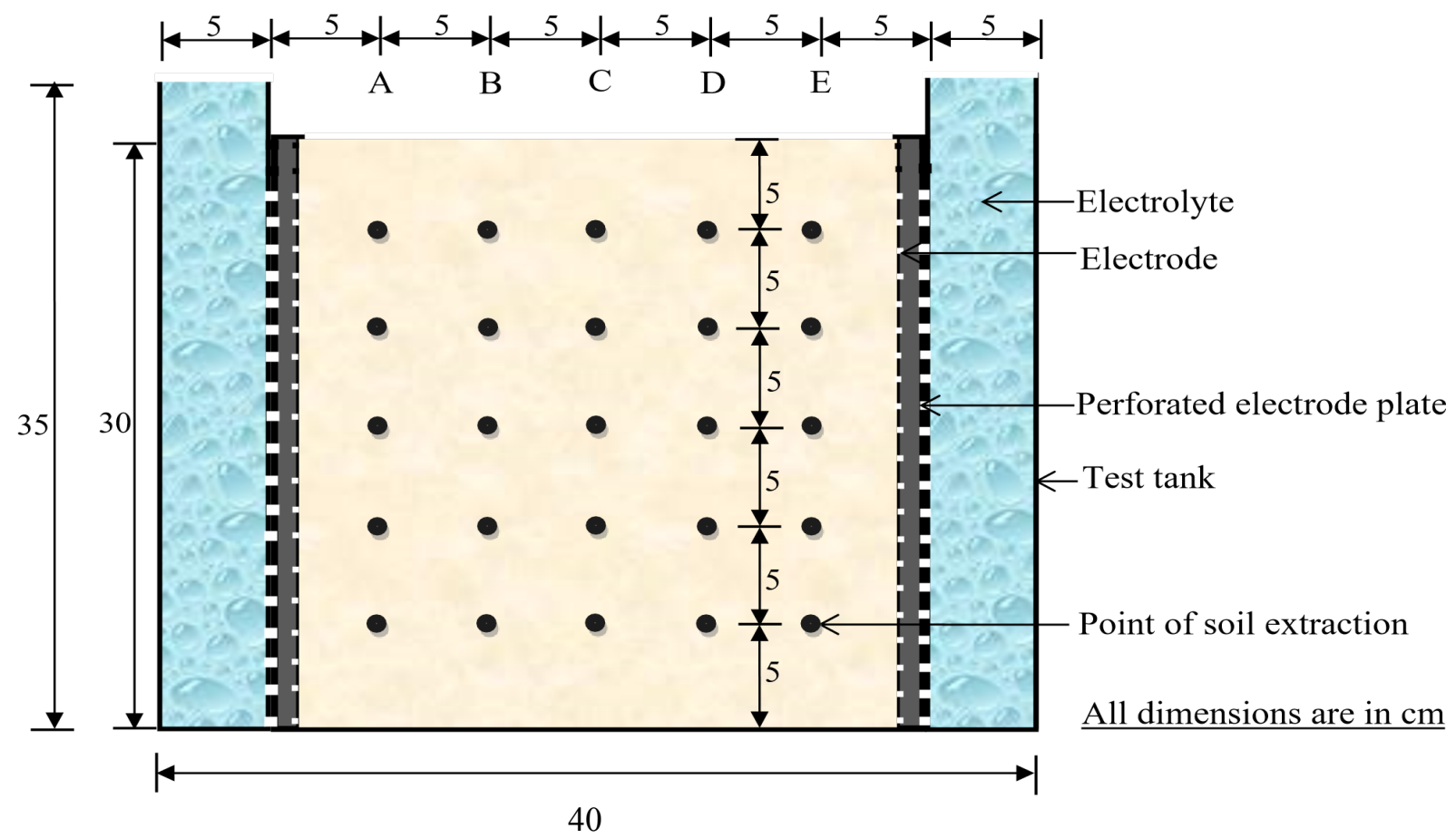

Figure 2. Cross-sectional view of the rectangular test tank setup.

\section{Power Supply Device}

An adjustable, power supply device of $30 \mathrm{~V}$ direct current DC was connected to the electrode plates in parallel arrays.

\section{EXPERIMENTAL SETUP}

Figure 1 presents the schematic diagram of the EK treatment setup. It is made up of a rectangular glass tank, 30 $\mathrm{V}$ power supply device, ionic solution chambers, and conductive perforated, rectangular electrode plates. Four test setups having different electrode lengths $\left(l_{e}\right)$ were designed and used in this study. The full dimension of the electrode length, $1_{\mathrm{e}}$ was shown in Figure 2. All the EK treatments were performed on soil samples at the in situ density and 
water content values given in Table 1. The walls of the test tanks were lubricated before placing the soil blocks in the test tanks. The soil blocks were tight-fitted inside the center chamber of the test tanks to prevent leakage of ionic solutions. The ionic solutions of $\mathrm{CaCl}_{2}$ and $\mathrm{Na}_{2} \mathrm{CO}_{3}$ were applied at the anode and cathode chambers of the test tanks, respectively. The filtering system was used to prevent the movement of soil fines from the soil block chamber into the ionic solution chambers. After the test setup, $1 \mathrm{~V} / \mathrm{m}$ was applied across the soil block for 28 days of EK treatment. At the end of the EK treatment, the soil specimens were extracted from the EK treated soils in the test tank locations indicated in Figure 2. The Atterberg limit tests and one-dimensional swelling were performed on the treated soils. The PI and the SP data obtained were analyzed and evaluated using the design of experiment (DOE) of the software program.

\section{METHODOLOGY}

The effects of ionic solutions on the EK treated soils under changing electrode lengths $\left(1_{\mathrm{e}}\right)$, varying soil depths $\left(d_{s}\right)$, and lengthwise anode to cathode distances $\left(d_{A \leftrightarrow E}\right)$ were considered. Though the soil depth $\left(d_{s}\right)$ and the anode to cathode distances $\left(\mathrm{d}_{\mathrm{A} \leftrightarrow \mathrm{E}}\right)$ were predetermined and fixed as shown in Figure 2, the length of the electrode was changing, and the effect of the electrode length $\left(l_{e}\right)$ at the predetermined points was investigated. The variation in the PI and SP values of the EK treated soils at these points was studied. The locations of extraction for PI determination were considered at points A, B, C, D, and E. Also, points A, C and E were selected in the SP determination of the EK treated soils. After that, the extracted EK treated soils were subjected to the Atterberg limit tests and onedimensional swelling tests according to ASTM D D4318 and ASTM D 4546, respectively. The data obtained from the PI and SP values were then subjected to advance statistical modeling for evaluating the most appropriate electrode length configurations to achieve the most effective performance for EK treatment. Modeling and analysis of the experimental results were conducted by response surface methodology (RSM), which was the combination of statistical and mathematical techniques useful for displaying and analyzing different variables (Montgomery et al. 2009). Table 3 presents the factors and their corresponding low, intermediate, and high-level ranges. Tables 4 and 5 show the number of the experimental test runs obtained from the test setup at different electrode lengths, $1_{\mathrm{e}}$ during the 28 days EK treatment duration. An average of three specimens was used to produce each outcome. The estimation of the adequacy of models was realizable by using analysis of variance (ANOVA), which showed the quality of selected models. The effect of the 28 days EK treatment performance on the PI and SP values of the EK treated soils were examined and analyzed for the electrode lengths $\left(l_{e}\right)$, soil depths $\left(d_{s}\right)$, and anode to cathode distances $\left(d_{A \leftrightarrow E}\right)$.

Table 3. Factors and their levels using the response surface methodology.

\begin{tabular}{|c|c|c|c|c|}
\hline Name & Symbols & \multicolumn{3}{|c|}{ Levels of Factors (cm) } \\
\hline Electrode length $\left(\mathrm{l}_{\mathrm{e}}\right)$ & $\mathrm{X}_{1}$ & 5 & 15 & 25 \\
\hline Soil depth $\left(\mathrm{d}_{\mathrm{s}}\right)$ & $\mathrm{X}_{2}$ & 7.5 & 15 & 30 \\
\hline $\begin{array}{c}\text { Lateral anode to } \\
\text { cathode distances } \\
\left(\mathrm{d}_{\mathrm{A} \leftrightarrow \mathrm{E}}\right)\end{array}$ & $\mathrm{X}_{3}$ & 5 & 15 & 25 \\
\hline
\end{tabular}




\section{Design of Experiments (DOE)}

In this study, small-scale laboratory pilot tests have been designed to investigate the effect of EK treatment on the PI and SP values of the given soil. The obtained data were used in the mathematical method of design of experiment (DOE) to analyze the interaction effect of the changing electrode lengths $\left(l_{e}\right)$, soil depths $\left(d_{s}\right)$, and anode to cathode distances $\left(\mathrm{d}_{\mathrm{A} \leftrightarrow \mathrm{E}}\right)$.

DOE is an advanced statistical, mathematical method to develop the interactive relationship between a few defined variables. DOE produces a large amount of informative and interpretative parameters from a few numbers of experimental data. The variables were individually useful in the output of the process with the minimum number of experiments. DOE method includes but is not limited to 2-Factorial design, 2FD, Multilevel Categoric design,

MCD and response surface methodology, RSM (Montgomery, 2017).

\section{Response Surface Methodology, RSM}

The modeling of results was performed by using response surface methodology (RSM). RSM examines the simultaneous interactive effect of input factors to achieve an optimum response, which is not achievable using conventional experimental methods (Kamani et al. 2018). The RSM design models include the linear, mean, 2-factor interaction, 2FI, quadratic, cubic, quartic, fifth, and sixth equations (Croarkin et al. 2006; Kaur et al. 2012). RSM was used to evaluate the effect of the input factors: the changing electrode length $\left(l_{e}\right)$, soil depth $\left(d_{s}\right)$, and anode to cathode distance $\left(\mathrm{d}_{\mathrm{A} \leftrightarrow \mathrm{E}}\right)$ on the responses: the PI and SP values of the EK treated soils. The obtained experimental PI and SP data were analyzed using the quadratic and 2FI models to examine the significance and interactive effects of the input factors on the output of responses.

\section{RESULTS AND DISCUSSION}

The performance of the EK treatment at different electrode lengths $\left(l_{e}\right)$, soil depths $\left(d_{s}\right)$, and anode to cathode distances $\left(\mathrm{d}_{\mathrm{A} \leftrightarrow \mathrm{E}}\right)$ was examined. Based on the findings, the changing electrode lengths $\left(l_{\mathrm{e}}\right)$ had some remarkable effects on the EK treated soils at different soil depths $\left(\mathrm{d}_{\mathrm{s}}\right)$, and lateral anode to cathode distances $\left(\mathrm{d}_{\mathrm{A} \leftrightarrow \mathrm{E}}\right)$ directions. Thus, depending on the target soil depth $\left(\mathrm{d}_{\mathrm{s}}\right)$, the suitable electrode length $\left(\mathrm{l}_{\mathrm{e}}\right)$ can be accurately modeled, designed, and configured to efficiently improve or stabilize the problematic soils using an RSM of the DOE.

\section{Analytical Interpretation of PI and SP Data}

Table 4 presents the plasticity index, PI values of the EK treated soils at different electrode lengths $\left(l_{\mathrm{e}}\right)$, soil depths $\left(\mathrm{d}_{\mathrm{s}}\right)$, and anode to cathode distances $\left(\mathrm{d}_{\mathrm{A} \leftrightarrow \mathrm{E}}\right)$. In the present study, the obtained PI and SP values of the EK treated soils with changing electrode length $\left(l_{e}\right)$ and at different soil depths $\left(d_{s}\right)$ measured at different points $A, B, C$, $D$, and E, shown in Figure 2 along lengthwise anode to cathode distances $\left(\mathrm{d}_{\mathrm{A} \leftrightarrow \mathrm{E}}\right)$ were examined and analyzed.

At points $\mathrm{A}$ and $\mathrm{E}$, the effects of $1.01_{\mathrm{e}}$ (full length of the electrode $=30 \mathrm{~cm}$ ) and $0.751_{\mathrm{e}}$ on the EK treated soils were similar, and the effects of $0.251_{\mathrm{e}}$ and $0.501_{\mathrm{e}}$ were also roughly identical to each other. The efficiency of the EK treatment was in the order of $1.01_{\mathrm{e}}>0.751_{\mathrm{e}}>0.501_{\mathrm{e}}>0.25 \mathrm{1}_{\mathrm{e}}$ along with the soil depth, $\mathrm{d}_{\mathrm{s}}$. The EK treatment is effective on the EK treated soils at points $\mathrm{A}$ and $\mathrm{E}$ due to proximity to the chambers housing the ionic solutions and the electrode plates. 
Table 4. Plasticity index (PI) values of EK treated soils at different $1_{e}, d_{s}$, and $d_{A \leftrightarrow E}$.

\begin{tabular}{|c|c|c|c|c|c|}
\hline \multirow{3}{*}{$\begin{array}{l}\text { Lateral anode to cathode distances }\left(\mathrm{d}_{\mathrm{A} . \mathrm{E}}\right) \\
(\mathrm{cm})\end{array}$} & \multirow{3}{*}{$\begin{array}{l}\text { Soil depth } \\
\begin{array}{c}\left(\mathbf{d}_{\mathbf{s}}\right) \\
(\mathbf{c m})\end{array}\end{array}$} & \multicolumn{4}{|c|}{$\begin{array}{l}\text { Electrode length (le) } \\
(\mathrm{cm})\end{array}$} \\
\hline & & 7.5 & 15.0 & 22.5 & 30.0 \\
\hline & & \multicolumn{4}{|c|}{$\begin{array}{c}\text { Plasticity index (PI) } \\
(\%) \\
\end{array}$} \\
\hline Natural soil & - & 27 & 27 & 27 & 27 \\
\hline \multirow{5}{*}{ Point A ( $5 \mathrm{~cm}$ distance from the anode) } & 5 & 23 & 21 & 21 & 21 \\
\hline & 10 & 24 & 23 & 22 & 21 \\
\hline & 15 & 25 & 25 & 22 & 21 \\
\hline & 20 & 24 & 23 & 22 & 20 \\
\hline & 25 & 25 & 22 & 22 & 20 \\
\hline \multirow{5}{*}{ Point B (10 cm distance from anode) } & 5 & 27 & 23 & 23 & 21 \\
\hline & 10 & 26 & 24 & 23 & 21 \\
\hline & 15 & 25 & 23 & 23 & 21 \\
\hline & 20 & 25 & 23 & 24 & 21 \\
\hline & 25 & 27 & 23 & 24 & 21 \\
\hline \multirow{5}{*}{ Point C (15 cm distance from anode) } & 5 & 27 & 25 & 25 & 23 \\
\hline & 10 & 27 & 25 & 25 & 23 \\
\hline & 15 & 27 & 26 & 24 & 23 \\
\hline & 20 & 27 & 26 & 24 & 23 \\
\hline & 25 & 26 & 26 & 24 & 23 \\
\hline \multirow{5}{*}{ Point D (20 cm distance from anode) } & 5 & 25 & 24 & 23 & 22 \\
\hline & 10 & 24 & 23 & 22 & 22 \\
\hline & 15 & 24 & 23 & 22 & 22 \\
\hline & 20 & 25 & 25 & 23 & 22 \\
\hline & 25 & 27 & 25 & 22 & 21 \\
\hline \multirow{5}{*}{ Point E (25 cm distance from anode) } & 5 & 24 & 22 & 23 & 22 \\
\hline & 10 & 24 & 21 & 21 & 22 \\
\hline & 15 & 24 & 23 & 21 & 21 \\
\hline & 20 & 25 & 22 & 21 & 20 \\
\hline & 25 & 27 & 24 & 20 & 20 \\
\hline
\end{tabular}

*circle represents the critical point $\left(\mathrm{C}_{\mathrm{p}}\right)$

At points $\mathrm{B}$ and $\mathrm{D}$, the effects of the changing electrode lengths $\left(\mathrm{l}_{\mathrm{e}}\right)$ on the PI values of the EK treated soils at different soil depths $\left(d_{s}\right)$ were less effective when compared to those at points $A$ and $E$. The efficiency of varying electrode lengths $\left(1_{\mathrm{e}}\right)$ was reduced due to an increasing distance from the anode/ionic solution chamber. Thus, at points $\mathrm{B}$ and $\mathrm{D}$, the efficacy of the EK treatment of soils was in the order of $1.01_{\mathrm{e}} \approx 0.751_{\mathrm{e}}>0.501_{\mathrm{e}} \approx 0.251_{\mathrm{e}}$ along with the soil depth $\left(\mathrm{d}_{\mathrm{s}}\right)$. At point $\mathrm{C}$, the effects of the changing electrode lengths $\left(\mathrm{l}_{\mathrm{e}}\right)$ on PI values of the EK treated soils at different soil depths $\left(d_{s}\right)$ showed that the efficiency of changing electrode lengths $\left(l_{e}\right)$ was significantly reduced due to a distance from the ionic solution chambers. Hence, at point $\mathrm{C}$, the efficacy of the EK treatment was in the order 
of $1.01_{\mathrm{e}} \approx 0.751_{\mathrm{e}} \approx 0.501_{\mathrm{e}} \approx 0.251_{\mathrm{e}}$ along with the soil depth $\left(\mathrm{d}_{\mathrm{s}}\right)$ direction. The least performance of EK treatment was recorded at point $\mathrm{C}$ due to the distance to both the anode and cathode ends, and the ionic solutions' chambers.

Table 5. Swelling potential (SP) values of EK treated soils at different $1_{e}, d_{s}$, and $d_{A \leftrightarrow E}$.

\begin{tabular}{|c|c|c|c|c|c|}
\hline \multirow{3}{*}{$\begin{array}{l}\text { Lateral anode to cathode distances }\left(d_{A_{\leftrightarrow} E}\right) \\
(\mathbf{c m})\end{array}$} & \multirow{3}{*}{$\begin{array}{l}\text { Soil depth }\left(d_{s}\right) \\
(\mathbf{c m})\end{array}$} & \multicolumn{4}{|c|}{$\begin{array}{c}\text { Electrode length }\left(\mathrm{l}_{\mathrm{e}}\right) \\
(\mathrm{cm})\end{array}$} \\
\hline & & 7.5 & 15.0 & 22.5 & 30.0 \\
\hline & & \multicolumn{4}{|c|}{$\begin{array}{c}\text { Swell potential (SP) } \\
(\%)\end{array}$} \\
\hline Natural soil & - & 1.20 & 1.62 & 1.62 & 1.62 \\
\hline \multirow{5}{*}{ Point A ( $5 \mathrm{~cm}$ distance from the anode) } & $5 \mathrm{~cm}$ & 1.33 & 0.95 & 0.85 & 0.73 \\
\hline & $10 \mathrm{~cm}$ & 1.48 & 0.97 & 0.89 & 0.68 \\
\hline & $15 \mathrm{~cm}$ & 1.48 & 1.14 & 0.99 & 0.62 \\
\hline & $20 \mathrm{~cm}$ & 1.46 & 1.16 & 1.13 & 0.62 \\
\hline & $25 \mathrm{~cm}$ & 1.49 & 1.37 & 1.16 & 0.55 \\
\hline \multirow{5}{*}{ Point $\mathrm{C}$ ( $15 \mathrm{~cm}$ distance from the anode) } & $5 \mathrm{~cm}$ & 1.51 & 1.45 & 1.38 & 1.37 \\
\hline & $10 \mathrm{~cm}$ & $\not .58$ & 1.45 & 1.36 & 1.35 \\
\hline & $15 \mathrm{~cm}$ & 1.57 & 1.44 & 1.36 & 1.32 \\
\hline & $20 \mathrm{~cm}$ & 1.59 & 1.43 & 1.35 & 1.29 \\
\hline & $25 \mathrm{~cm}$ & 1.51 & 1.43 & 1.34 & 1.28 \\
\hline \multirow{5}{*}{ Point E (25 cm distance from the anode) } & $5 \mathrm{~cm}$ & 1.31 & 1.05 & 0.98 & 0.87 \\
\hline & $10 \mathrm{~cm}$ & 1.58 & 1.07 & 1.02 & 0.95 \\
\hline & $15 \mathrm{~cm}$ & 1.57 & 1.24 & 1.05 & 1.02 \\
\hline & $20 \mathrm{~cm}$ & 1.59 & 1.33 & 1.08 & 1.05 \\
\hline & $25 \mathrm{~cm}$ & 1.61 & 1.57 & 1.24 & 1.05 \\
\hline
\end{tabular}

* circle represents the critical point $\left(\mathrm{C}_{\mathrm{p}}\right)$

Table 5 presents the swelling potential (SP) values at different electrode lengths $\left(l_{e}\right)$, soil depths $\left(d_{s}\right)$, and lateral anode to cathode distances $\left(\mathrm{d}_{\mathrm{A} \leftrightarrow \mathrm{E}}\right)$. At point $\mathrm{E}$, the effects of electrode lengths $1.01_{\mathrm{e}}$ and $0.751_{\mathrm{e}}$ were similar but more significant than the effects of $0.251_{\mathrm{e}}$ and $0.501_{\mathrm{e}}$, and high-performance efficiency was observed, due to proximity to the ionic solution cells.

For the SP of the EK treated soils, at points $\mathrm{A}$ and $\mathrm{E}$, the effects of changing electrode length $\left(\mathrm{l}_{\mathrm{e}}\right)$ at different soil depths $\left(d_{s}\right)$ can be observed to decrease along the soil depths $\left(d_{s}\right)$. In general terms, for the PI and the SP of the EK treated soils, the efficiency of electrode length $\left(1_{e}\right)$ was in the order of $1.01_{e}>0.751_{e}>0.501_{e}>0.251_{e}$. Thus, it was observed that the experimental results depend on the surface area contact of the electrode plates with the EK treated soils. Also, with the proximity and the electroosmotic driving flow of ionic solutions along with both the soil depth $\left(\mathrm{d}_{\mathrm{s}}\right)$ and lateral anode to cathode distance $\left(\mathrm{d}_{\mathrm{A} \leftrightarrow \mathrm{E}}\right)$ directions.

\section{Critical Points, $C_{P}$ for PI and SP Data}

Tables 4 and 5 present the experimental data of the PI, and the SP of the EK treated soils. The critical points $\left(C_{p}\right)$ were defined at the predetermined locations of soil extraction in the test tanks for given input factors. The $C_{p}$ is 
the least active region where the obtained data of the PI values in the EK treated soils were close to the PI values of the natural in situ soil, as shown in Tables 4 and 5 by the circle symbol. The $\mathrm{C}_{\mathrm{p}}$ was used to analyze the effect of experimental factors on the PI, and the SP of the EK treated soils. Furthermore, the $\mathrm{C}_{\mathrm{p}}$ was used as a reference point in the response surface methodology (RSM) to examine the most significant input factors, and their interactive effects at the critical engineering condition on the PI and the SP values of the EK treated soils. The significant input factors at the $\mathrm{C}_{\mathrm{p}}$ may be deemed suitable and enable geotechnical engineers to navigate a design space for the large scale in situ application of ground improvement. The $\mathrm{C}_{\mathrm{p}}$ for the PI and the SP values of the EK treated soils at different electrode lengths $\left(l_{e}\right)$, soil depths $\left(d_{s}\right)$, and lateral anode to cathode distances $\left(d_{A \leftrightarrow E}\right)$ was given in the relationships below as

$d_{\mathrm{s}}$ versus $d_{A \leftrightarrow E}$ at critical electrode length $\left(1_{\mathrm{e}}\right)$ of $15 \mathrm{~cm}$;

$1_{e}$ versus $d_{A \leftrightarrow E}$ at critical soil depth $\left(d_{s}\right)$ of $15 \mathrm{~cm} ; d_{s}$ versus $1_{\mathrm{e}}$ at critical lateral distances $\left(\mathrm{d}_{\mathrm{A} \leftrightarrow \mathrm{E}}\right)$ of $15 \mathrm{~cm}$.

\section{STATISTICAL INTERPRETATIONS OF INPUT FACTORS}

In this study, the RSM generated the analysis of variance (ANOVA) and the predictive model parameters, which were used to determine the interactive effects of the input factors and responses. The ANOVA determined the adequacy of the selected model terms. The 2FI and quadratic models were considered to determine the precise predictive model; and the significant factors for the responses. The probability $\mathrm{p}$-values $\leq 0.05<\mathrm{P}<0.10$ indicates the model term is significant. The values $\mathrm{p}>0.10$ indicate the model term is not significant. The fit statistic shows a reasonable agreement when the $R^{2}$ is high, and the adjusted $R^{2}$ minus predicted $R^{2}$ is $\leq 0.2$ (Wang et al. 2008). The $\mathrm{R}^{2}$ determines the quality of the predictive model by the deviation of the variables. The adequate precision measures the signal to noise ratio. According to Myers and Montgomery (1995), an adequate precision ratio $>4$ is more desirable in the ANOVA analysis. Montgomery (2017) stated that the F-value is high, and an insignificant percent chance that the large F-value could occur due to noise indicates that the model is statistically significant.

Table 6. ANOVA for PI of EK treated soils at changing $1_{e}$ at different $d_{s}$ and $d_{A \leftrightarrow E}$.

\begin{tabular}{|c|c|c|c|c|c|c|}
\hline \multicolumn{2}{|l|}{$\begin{array}{c}\text { Sum of } \\
\text { Source Squares }\end{array}$} & \multirow{2}{*}{$\begin{array}{l}\text { df } \\
9\end{array}$} & \multirow{2}{*}{\begin{tabular}{|l|} 
Mean Square \\
37.32 \\
\end{tabular}} & \multicolumn{2}{|c|}{ F-value p-value } & \\
\hline Model & 335.92 & & & 44.79 & $<0.0001$ & significant \\
\hline $\mathrm{X}_{1}$ : Electrode length $\left(\mathrm{l}_{\mathrm{e}}\right)$ & 137.64 & 1 & 137.64 & 165.18 & $<0.0001$ & significant \\
\hline $\mathrm{X}_{2}$ : Soil depth $\left(\mathrm{d}_{\mathrm{s}}\right)$ & 0.2160 & 1 & 0.2160 & 0.2592 & 0.6119 & \\
\hline $\mathrm{X}_{3}$ : Anode to cathode distance $\left(\mathrm{d}_{\mathrm{A} \leftrightarrow \mathrm{E}}\right)$ & 6.02 & 1 & 6.02 & 7.22 & 0.0086 & significant \\
\hline $\mathrm{X}_{1} \mathrm{X}_{2}$ & 6.56 & 1 & 6.56 & 7.87 & 0.0061 & significant \\
\hline $\mathrm{X}_{1} \mathrm{X}_{3}$ & 0.4000 & 1 & 0.4000 & 0.4801 & 0.4902 & \\
\hline $\mathrm{X}_{2} \mathrm{X}_{3}$ & 1.56 & 1 & 1.56 & 1.88 & 0.1743 & \\
\hline $\mathrm{X}_{1}^{2}$ & 13.69 & 1 & 13.69 & 16.43 & 0.0001 & significant \\
\hline $\mathrm{X}_{2}^{2}$ & 0.0893 & 1 & 0.0893 & 0.1072 & 0.7442 & \\
\hline $\mathrm{X}_{3}^{2}$ & 126.23 & 1 & 126.23 & 151.49 & $<0.0001$ & significant \\
\hline Residual & 74.99 & 90 & 0.8332 & & & \\
\hline Cor Total & 410.91 & 99 & & & & \\
\hline
\end{tabular}




\section{Statistical Interpretations of PI Data}

Table 6 presents the ANOVA analysis for the PI values obtained from the EK treated soils. The probability, pvalue less than 0.05 , indicated that the factors, $X_{1}$, electrode length $\left(l_{e}\right), X_{3}$, lateral anode to cathode distances $\left(\mathrm{d}_{\mathrm{A} \leftrightarrow \mathrm{E}}\right)$, and $\mathrm{X}_{1}$, electrode length $\left(\mathrm{l}_{\mathrm{e}}\right)$ and $\mathrm{X}_{2}$, soil depth $\left(\mathrm{d}_{\mathrm{s}}\right)$ combination were significant model terms. The PI values changed significantly along the fixed factor $\mathrm{X}_{2}$ : soil depth $\left(\mathrm{d}_{\mathrm{s}}\right)$, which on its own was not a considerable model term.

In this case, $\mathrm{X}_{1}, \mathrm{X}_{3}, \mathrm{X}_{1} \mathrm{X}_{2}, \mathrm{X}_{1}^{2}, \mathrm{X}_{3}^{2}$ were substantial model terms and had a considerable effect on the PI values of the EK treated soils. The input and interactive effect of factors $X_{2}, X_{1} X_{3}$, and $X_{2} X_{3}$ model terms were negligible on the PI of the EK treated soils. The model F-value $=44.79$ of the ANOVA analysis implied that the model term was significant. Figure $3 a$ presents the predicted PI versus actual PI values. The actual $\mathrm{R}^{2}$ value, predicted $\mathrm{R}^{2}$ value, and adjusted $\mathrm{R}^{2}$ were $0.8175,0.7992$, and 0.7783 , respectively. The high actual $\mathrm{R}^{2}$, the predicted $\mathrm{R}^{2}$, and the adjusted $\mathrm{R}^{2}$ values indicated strong agreement between the experimental and the model values obtained. The adequate precision ratio of 26.81 was $>4$ showed an appropriate signal.

\section{Statistical Interpretations of SP Data}

Table 7 presents the ANOVA analysis for the SP values of the EK treated soils. The obtained probability, a pvalue $<0.05$, showed that the factors, $\mathrm{X}_{1}$ : electrode length $\left(l_{\mathrm{e}}\right), \mathrm{X}_{2}$ : soil depth $\left(\mathrm{d}_{\mathrm{s}}\right)$, and $\mathrm{X}_{3}$ : lateral anode to cathode distances $\left(\mathrm{d}_{\mathrm{A} \leftrightarrow \mathrm{E}}\right)$ were significant model terms.

Table 7. ANOVA for SP of EK treated soils at changing $l_{e}$ at different $d_{s}$ and $d_{A \leftrightarrow E}$.

\begin{tabular}{|lr|r|r|l|l|l|}
\hline \multicolumn{2}{|c|}{$\begin{array}{c}\text { Sum of } \\
\text { Source Squares }\end{array}$} & & df & \multicolumn{2}{c|}{ Mean Square } & \multicolumn{2}{c|}{ F-value p-value } & \\
\hline Model & 3.01 & 6 & 0.5019 & 58.26 & $<0.0001$ & significant \\
\hline $\mathrm{X}_{1}$ : Electrode length $\left(\mathrm{l}_{\mathrm{e}}\right)$ & 2.06 & 1 & 2.06 & 239.60 & $<0.0001$ & significant \\
\hline $\mathrm{X}_{2}$ : Soil depth $\left(\mathrm{d}_{\mathrm{s}}\right)$ & 0.4947 & 1 & 0.4947 & 57.41 & $<0.0001$ & significant \\
\hline $\mathrm{X}_{3}$ : Anode to cathode distance $\left(\mathrm{d}_{\mathrm{A} \leftrightarrow \mathrm{E}}\right)$ & 0.1814 & 1 & 0.1814 & 21.05 & $<0.0001$ & significant \\
\hline $\mathrm{X}_{1} \mathrm{X}_{2}$ & 0.0041 & 1 & 0.0041 & 0.4758 & 0.4951 & \\
\hline $\mathrm{X}_{1} \mathrm{X}_{3}$ & 0.0464 & 1 & 0.0464 & 5.38 & 0.0267 & significant \\
\hline $\mathrm{X}_{2} \mathrm{X}_{3}$ & 0.0009 & 1 & 0.0009 & 0.1058 & 0.7471 & \\
\hline Residual & 0.2843 & 33 & 0.0086 & & & \\
\hline Cor Total & 3.30 & 39 & & & \\
\hline
\end{tabular}

Also, it showed that the interactive effect between the $\mathrm{X}_{1}$, electrode length $\left(\mathrm{l}_{\mathrm{e}}\right)$, and $\mathrm{X}_{3}$, lateral anode to cathode distances $\left(\mathrm{d}_{\mathrm{A} \leftrightarrow \mathrm{E}}\right)$ combination was a significant model term. 
Design-Expert $(\AA)$ Software Swelling potential, SP $(\%)$

Color points by value of Swelling potential, SP (\%): 0.55
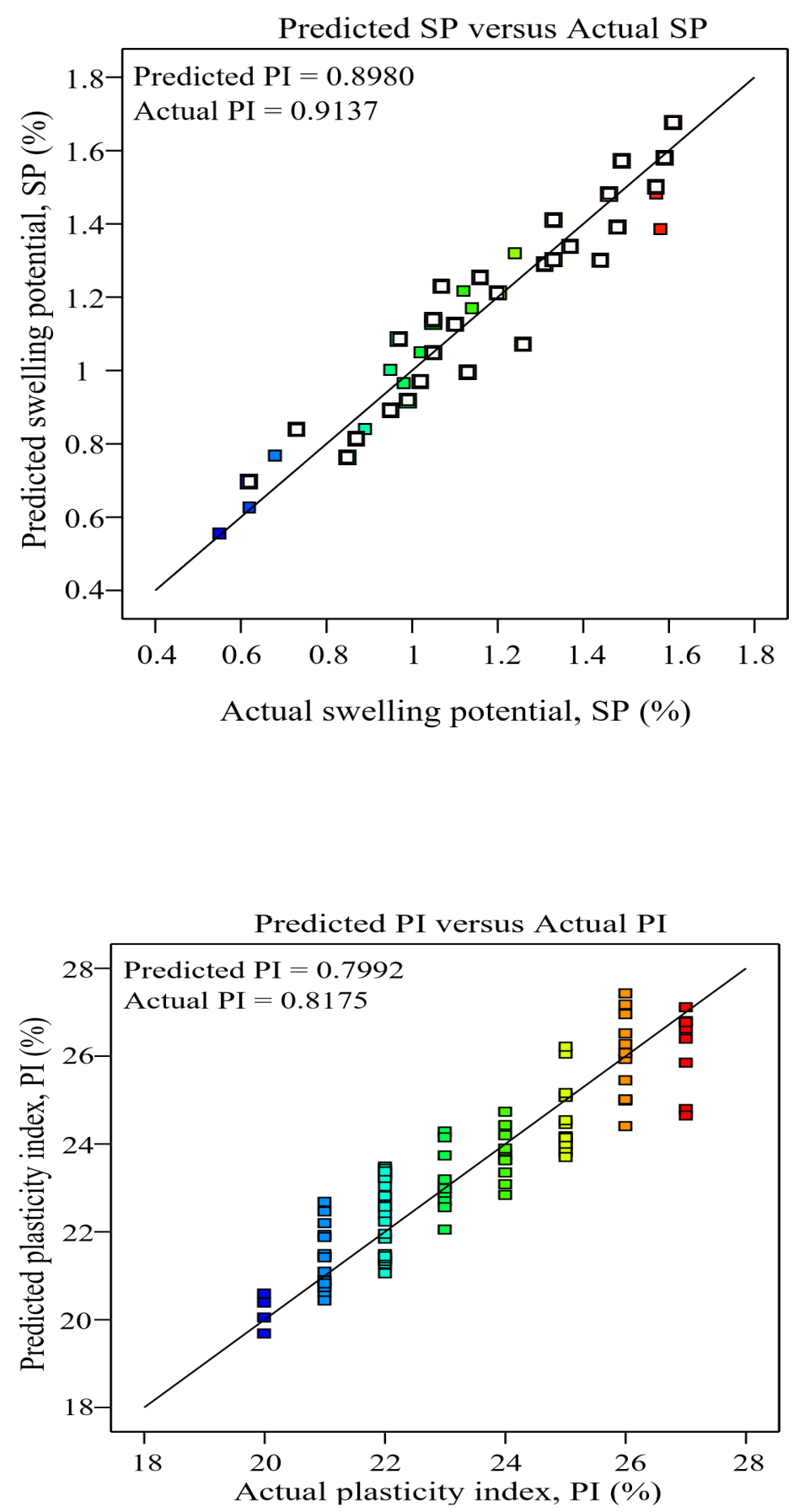

(a)

Figure 3. Predictive model for (a) plasticity index, PI (b) swelling potential, SP of the EK treated soils. 
In this case, $\mathrm{X}_{1}, \mathrm{X}_{2}, \mathrm{X}_{3}, \mathrm{X}_{1} \mathrm{X}_{3}$ were significant model terms, having a considerable effect on the SP response. Values greater than 0.10 indicated that the model terms were not significant. The interactive effect of factors $\mathrm{X}_{1} \mathrm{X}_{2}$ and $\mathrm{X}_{2} \mathrm{X}_{3}$ model terms were negligible on the EK treated soils. The model F-value is 58.26, and it shows that the model term was significant, given in the predictive model for the SP values (Figure $3 b$ ). The actual $\mathrm{R}^{2}$ value was 0.9137 . The predicted $R^{2}$ value and the adjusted $R^{2}$ were 0.8980 and 0.8782 , respectively; and their difference was $<$ 0.2 . The high actual $R^{2}$, the predicted $R^{2}$, and the adjusted $R^{2}$ values indicated a strong agreement between the experimental and model values. The adequate precision ratio of $29.01>4$ showed a fit signal.

\section{Effects of Electrode Length, $\mathbf{l}_{\mathrm{e}}$ Versus Soil Depth, $\mathbf{d}_{\mathrm{s}}$ on PI}

Figure 4 presents the response surface plots for electrode length $\left(l_{e}\right)$, and soil depth $\left(d_{s}\right)$, to examine their significant effects on PI values of the EK treated soils.

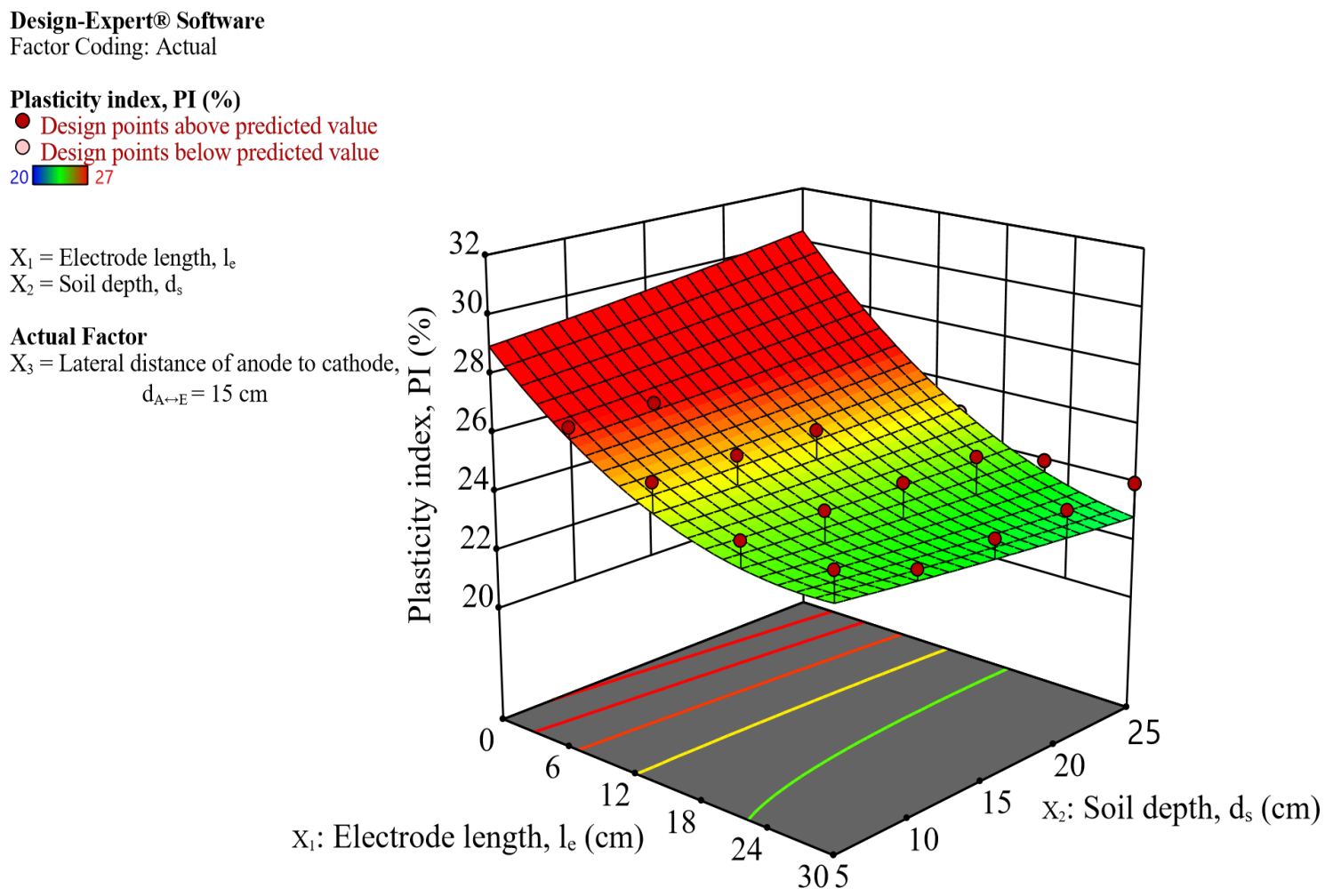

Figure 4. Effects of electrode length, $l_{\mathrm{e}}$ versus soil depth, $\mathrm{d}_{\mathrm{s}}$ on plasticity index, PI of EK treated soils.

It was observed that EK treated soils exhibited their lowest PI values at the higher electrode length (le), and the highest PI values at the shortest electrode length along with the changing deeper soil layers. At the $\mathrm{C}_{\mathrm{p}}$ of the soil, the effects of the different electrode lengths, $1.01_{\mathrm{e}}, 0.751_{\mathrm{e}}$, and $0.501_{\mathrm{e}}$, were significant for the total soil depth $\left(\mathrm{d}_{\mathrm{s}}\right)$ of 30 $\mathrm{cm}$, whereas the effect of $0.251_{\mathrm{e}}$ was not significant for the entire soil depth $\left(\mathrm{d}_{\mathrm{s}}\right)$. An indication that the performance of the EK treatment of soils depends on the surface area contact of the electrodes, their interaction with the ionic solutions, and their potential to discharge electrical energy along the soil depth $\left(\mathrm{d}_{\mathrm{s}}\right)$.

The observation was that the changing electrode length $\left(l_{\mathrm{e}}\right)$ significantly affected the performance of the EK treated soils. The changing electrode length $\left(l_{\mathrm{e}}\right)$ aided changes in the clay-ionic solutions reactions, thus altering the 
PI values of the EK treated soils. In terms of electrode length $\left(l_{\mathrm{e}}\right)$ to soil depth $\left(\mathrm{d}_{\mathrm{s}}\right)$ ratio; the $0.501_{\mathrm{e}}$ and $0.751_{\mathrm{e}}$ were suitable enough to achieve significant performance on the EK treatment for the targeted soil depth $\left(\mathrm{d}_{\mathrm{s}}\right)$.

\section{Effects of Electrode Length, $\mathrm{I}_{\mathrm{e}}$ Versus Lateral Anode to Cathode Distances, $\mathrm{D}_{\mathrm{A} \leftrightarrow \mathrm{E}}$ on PI}

Figure 5 presents the response surface model and interactive effect plots between the electrode length $\left(l_{\mathrm{e}}\right)$, and anode to cathode distances $\left(\mathrm{d}_{\mathrm{A} \leftrightarrow \mathrm{E}}\right)$ to examine their effects on PI values of the EK treated soils. The EK treated soils were observed to display their lowest PI values at the higher electrode length $\left(l_{\mathrm{e}}\right)$, especially at the points of extraction with the closest proximity to the anode and cathode plates in the ionic solution chambers.

The changing electrode length $\left(l_{\mathrm{e}}\right)$ had a significant effect on PI values of the EK treated soil along the lengthwise anode to cathode distances $\left(\mathrm{d}_{\mathrm{A} \leftrightarrow \mathrm{E}}\right)$ at the selected critical point $\left(\mathrm{C}_{\mathrm{p}}\right)$ for soil depth $\left(\mathrm{d}_{\mathrm{s}}\right), 15 \mathrm{~cm}$. It was observed that at higher electrode length $\left(l_{\mathrm{e}}\right)$ the EK treated soils exhibited their lowest PI values at the anode to cathode distances $\left(\mathrm{d}_{\mathrm{A} \leftrightarrow \mathrm{E}}\right)$ at the points $\mathrm{A}$ and $\mathrm{E}$ in both the lateral and the depth directions. An indication that the performance and effectiveness of the EK treatment depend on the surface area and proximity of the electrodes. The longer the electrode length $\left(l_{e}\right)$ the higher the surface area it covers within a soil system, thus the higher the clay-ionic solution reactions, alteration of the soil chemistry, and effective improvement of the EK treated soils. The response surface plots indicated that the PI values were lowest at higher electrode length $\left(l_{\mathrm{e}}\right)$ and the points A and E, the anodic and cathodic ends, respectively.

\section{Design-Expert ${ }^{\circledR}$ Software}

Factor Coding: Actual

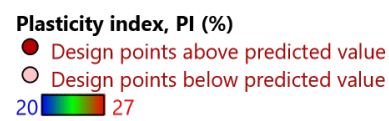

$\mathrm{X}_{1}=$ Electrode length, $\mathrm{l}_{\mathrm{e}}$

$\mathrm{X}_{3}=$ Lateral of anode to cathode distance, $\mathrm{d}_{\mathrm{A} \leftrightarrow \mathrm{E}}=15 \mathrm{~cm}$

Actual Factor:

$\mathrm{X}_{2}$ : Soil depth, $\mathrm{d}_{\mathrm{s}}=15 \mathrm{~cm}$

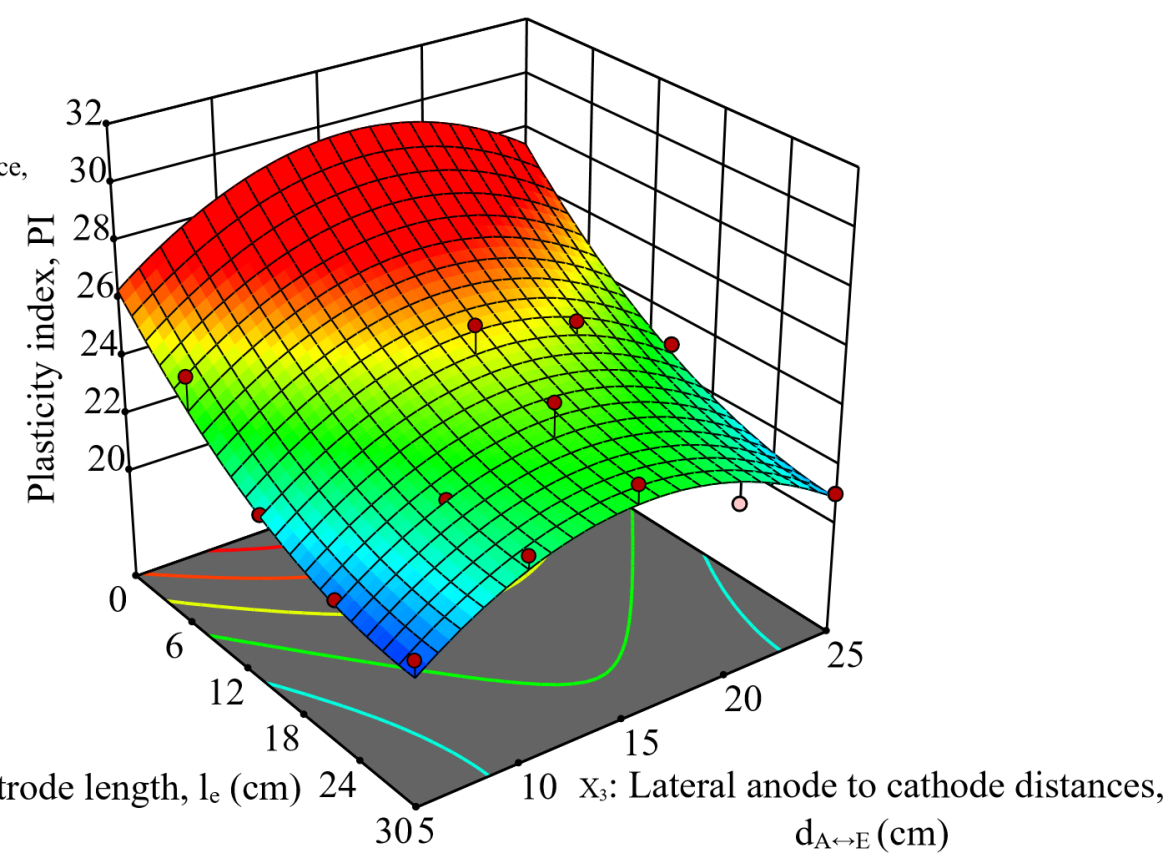

Figure 5. Effects electrode length, $1_{\mathrm{e}}$ versus anode to cathode distances, $\mathrm{d}_{\mathrm{A} \leftrightarrow \mathrm{E}}$ on plasticity index, PI of EK treated soils. 


\section{Effects of Soil Depth, $d_{\mathrm{s}}$ Versus Anode to Cathode Distances, $d_{\mathrm{A} \leftrightarrow \mathrm{E}}$ on PI}

Figure 6 presents the response surface plots to ascertain how significant the ionic solutions were effectively changing the PI values of the EK treated soils along soil depth $\left(\mathrm{d}_{\mathrm{s}}\right)$, and lateral anode to cathode distances $\left(\mathrm{d}_{\mathrm{A} \leftrightarrow \mathrm{E}}\right)$.

The performance of EK treatment is more active along the anode to cathode distances

$\left(\mathrm{d}_{\mathrm{A} \leftrightarrow \mathrm{E}}\right)$ when compared with the corresponding soil depths $\left(\mathrm{d}_{\mathrm{s}}\right)$ at the same points of extraction. It was observed that the EK-treated soils exhibited a significant reduction of PI values at points A and E in both the lateral and depth directions. The nearer the proximity, the higher the clay-ionic solutions reactions, altered the soil chemistry, and improved the treated soils effectively. The response surface plots indicated that the PI values in the EK treated soils were at the lowest, near to the anodic and cathodic ends, but the PI values were high at the critical point $\left(\mathrm{C}_{\mathrm{p}}\right)$.

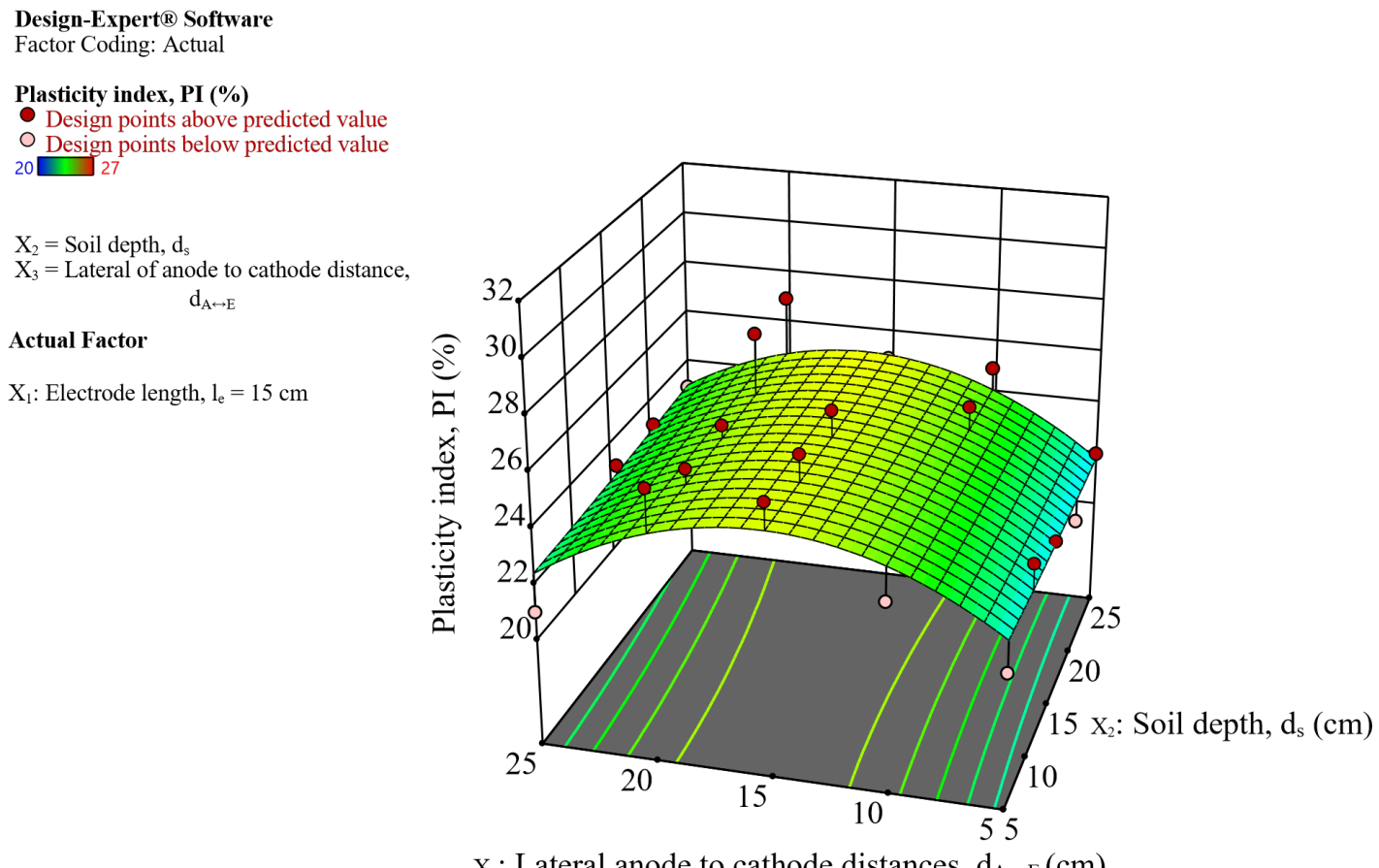

$\mathrm{X}_{3}$ : Lateral anode to cathode distances, $\mathrm{d}_{\mathrm{A} \leftrightarrow \mathrm{E}}(\mathrm{cm})$

Figure 6. Effects soil depth, $d_{s}$ versus anode to cathode distances, $d_{A \leftrightarrow E}$ on plasticity index, PI of EK treated soils.

\section{Effects of Electrode Length, $l_{e}$ Versus Soil Depth, $d_{s}$ on SP}

It was observed in the response surface plots that the changes in electrode length $\left(l_{\mathrm{e}}\right)$ caused ionic solutions to have different changing effects on the SP values of the EK treated soils along different soil depths $\left(\mathrm{d}_{\mathrm{s}}\right)$ (Figure 7).

The critical point $\left(\mathrm{C}_{\mathrm{p}}\right)$ for the lateral anode to cathode distances $\left(\mathrm{d}_{\mathrm{A} \leftrightarrow \mathrm{E}}\right)$ at points $\mathrm{A}$ and $\mathrm{E}$ was taken to be $15 \mathrm{~cm}$ mid-point. It was observed that high electrode length $\left(l_{\mathrm{e}}\right)$ had caused a significant reduction in the SP at the deeper soil layer, while short electrode length $\left(l_{\mathrm{e}}\right)$ had little reduction effect on SP at the deeper soil layer. The changing electrode length $\left(l_{\mathrm{e}}\right)$ has a significant performance on the SP of the EK treated soils along different soil depths $\left(\mathrm{d}_{\mathrm{s}}\right)$. 


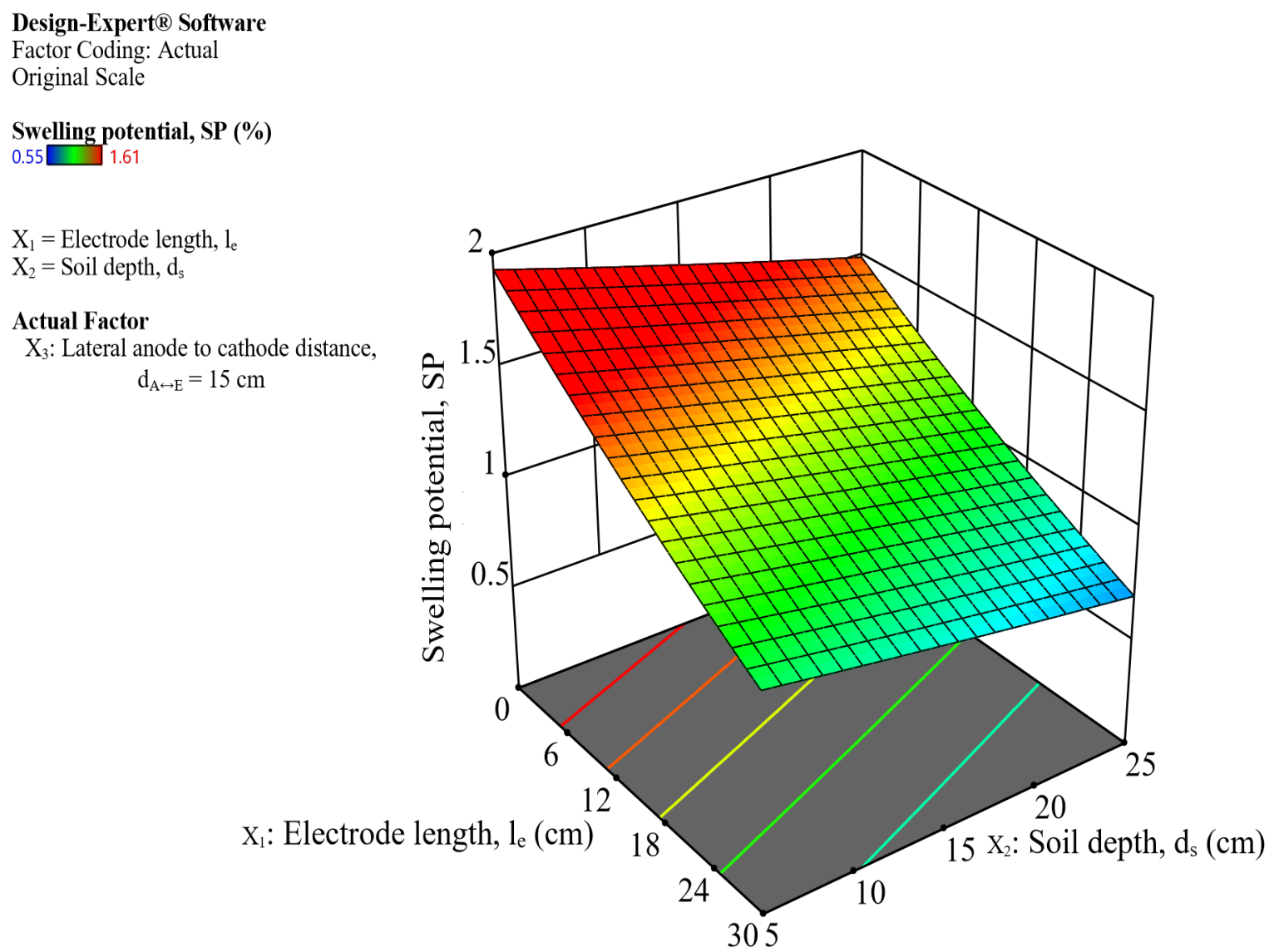

Figure 7. Effects of electrode length, $1_{\mathrm{e}}$ versus soil depth, $\mathrm{d}_{\mathrm{s}}$ on swelling potential, SP of EK treated soils.

The considerable reduction in the SP values along the soil depth $\left(\mathrm{d}_{\mathrm{s}}\right)$ conforms to the PI analysis of the EK treated soils at similar points of extraction. The observation was that the ionic solutions became effective, interacting with a longer electrode length $\left(l_{e}\right)$, discharging high potential electrical energy gradient along with their flow of direction.

\section{Effects of Electrode Length, $l_{e}$ Versus Lateral Anode to Cathode Distances, $d_{A \leftrightarrow E}$ on SP}

Figure 8 presents the response surface plots of electrode length $\left(l_{e}\right)$ versus anode to cathode distances $\left(d_{A \leftrightarrow E}\right)$. The changes in electrode length $\left(l_{e}\right)$ had a significant reduction in SP values of the EK treated soils. The high electrode length $\left(l_{\mathrm{e}}\right)$ had a significant reduction effect on SP, while the low electrode length $\left(l_{\mathrm{e}}\right)$ had little effect on the SP values of the EK treated soils at the critical point $\left(\mathrm{C}_{\mathrm{p}}\right)$ of soil depth $\left(\mathrm{d}_{\mathrm{s}}\right), 15 \mathrm{~cm}$. The lateral flow of the ionic solutions along anode to cathode distances $\left(\mathrm{d}_{\mathrm{A} \leftrightarrow \mathrm{E}}\right)$, specifically at points $\mathrm{A}$ and $\mathrm{E}$, at the anode to cathode ends, respectively, significantly altered the SP values at those points. 
Design-Expert ${ }^{\circledR}$ Software

Factor Coding: Actual

Original Scale

Swelling potential, SP (\%)

- Design points above predicted value

$O$ Design points below predicted value

$0.55 \square 1.61$

$\mathrm{X}_{1}=$ Electrode length, $\mathrm{l}_{\mathrm{e}}$

$\mathrm{X}_{3}=$ Lateral anode to cathode distance,

$\mathrm{d}_{\mathrm{A} \leftrightarrow \mathrm{E}}$

Actual Factor

$\mathrm{X}_{2}$ : Soil depth, $\mathrm{d}_{\mathrm{s}}=15 \mathrm{~cm}$

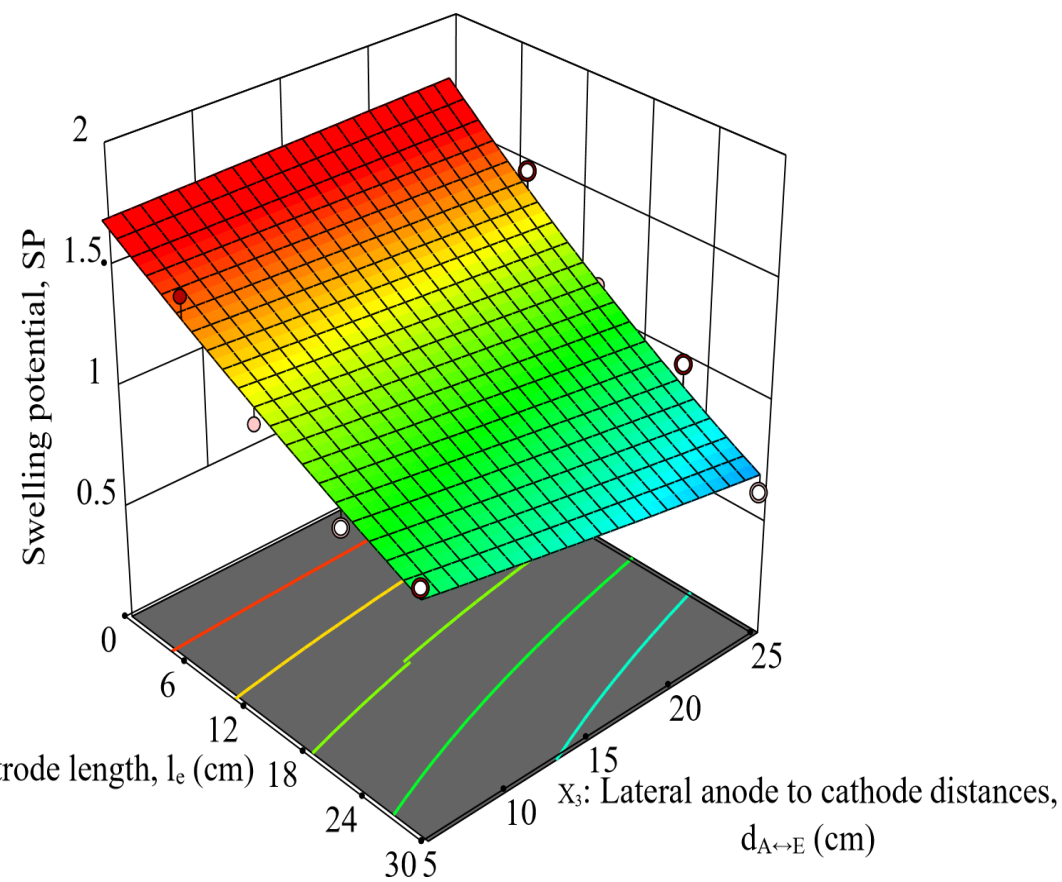

Figure 8. Effects of electrode length, $1_{\mathrm{e}}$ versus anode to cathode distances, $\mathrm{d}_{\mathrm{A} \leftrightarrow \mathrm{E}}$ on swelling potential, SP of EK treated soils.

\section{Effects of Soil Depth, $d_{s}$ Versus Anode to Cathode Distances, $d_{A \leftrightarrow E}$ on SP}

Figure 9 presents the soil depth $\left(d_{s}\right)$ correlation with the anode to cathode distances $\left(d_{A \leftrightarrow E}\right)$, specifically at points $\mathrm{A}$ and $\mathrm{E}$, at the anode to cathode ends, respectively. To define the effect of the changing in the electrode length $\left(1_{\mathrm{e}}\right)$, which showed that the SP values of the EK treated soils had a significant reduction at points of extraction of A and $\mathrm{E}$, but less reduction at $\mathrm{C}$.

\section{BUILDING SP AND PI FORMULAS}

The following equations for the PI and SP values of the EK treated soils were obtained through statistical analysis using the Stat-Ease software program. The equations were developed to build a relationship between the PI and SP values with the selected input factors, the electrode length $\left(l_{\mathrm{e}}\right)$, soil depth $\left(\mathrm{d}_{\mathrm{s}}\right)$, and anode to cathode distances $\left(\mathrm{d}_{\mathrm{A} \leftrightarrow \mathrm{E}}\right)$.

$$
\begin{aligned}
& \mathrm{PI}=23.29+0.043 \mathrm{~d}_{\mathrm{s}}-0.38 \mathrm{l}_{\mathrm{e}}+0.6765 \mathrm{~d}_{\mathrm{A} \leftrightarrow \mathrm{E}}-0.0057 \mathrm{~d}_{\mathrm{s}} * \mathrm{l}_{\mathrm{e}}+0.0025 \mathrm{~d}_{\mathrm{s}} * \mathrm{~d}_{\mathrm{A} \leftrightarrow \mathrm{E}}-0.00111_{\mathrm{e}} * \mathrm{~d}_{\mathrm{A} \leftrightarrow \mathrm{E}}+0.00089 \mathrm{~d}_{\mathrm{s}}^{2}+ \\
& 0.008 \mathrm{l}_{\mathrm{e}}^{2}-0.022 \mathrm{~d}_{\mathrm{A} \leftrightarrow \mathrm{E}^{2}}(1) \\
& \mathrm{SP}=1.99-0.024 \mathrm{l}_{\mathrm{e}}-0.021 \mathrm{~d}_{\mathrm{s}}-0.0023 \mathrm{~d}_{\mathrm{A} \leftrightarrow \mathrm{E}}+0.00017 \mathrm{l}_{\mathrm{e}} * \mathrm{~d}_{\mathrm{S}}-0.00041 \mathrm{l}_{\mathrm{e}} * \mathrm{~d}_{\mathrm{A} \leftrightarrow \mathrm{E}}+000068 \mathrm{~d}_{\mathrm{s}} * \mathrm{~d}_{\mathrm{A} \leftrightarrow \mathrm{E}} \quad \text { (2) }
\end{aligned}
$$




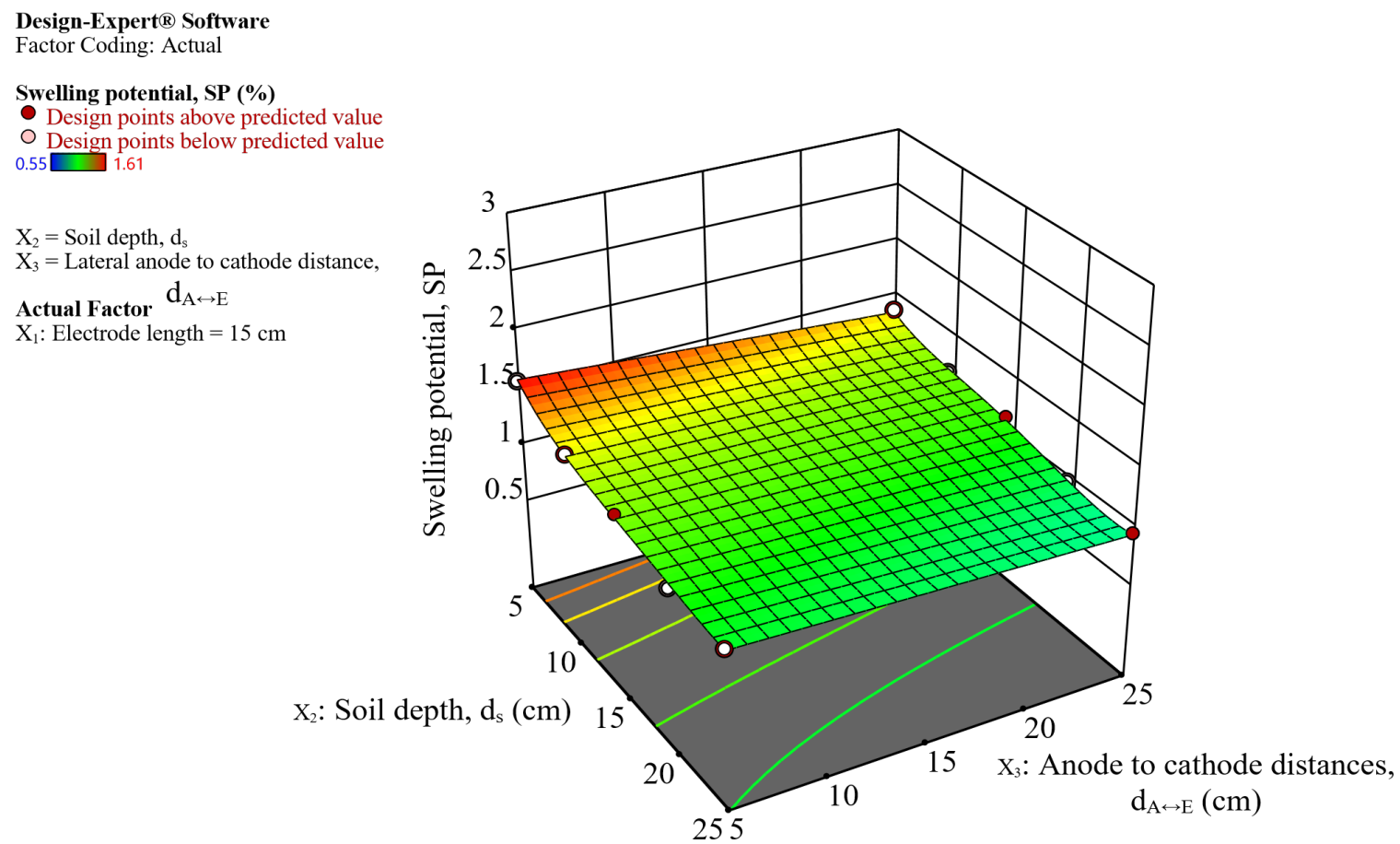

Figure 9. Effects soil depth, $d_{s}$ versus anode to cathode distances, $d_{A \leftrightarrow E}$ on swelling potential, SP of EK treated soils.

Thus, obtaining such equations can be used to estimate the required electrode length $\left(l_{\mathrm{e}}\right)$ for a given soil depth $\left(\mathrm{d}_{\mathrm{s}}\right)$, and anode to cathode distances $\left(\mathrm{d}_{\mathrm{A} \leftrightarrow \mathrm{E}}\right)$ to achieve specific PI and SP values in the EK treatment for a wide range of problematic soils in large field applications.

\section{CONCLUSION}

The design of an experiment to examine the significant effects of changing electrode length $\left(1_{\mathrm{e}}\right)$ on the determined PI and SP values of the EK treated soils along with the soil depth $\left(\mathrm{d}_{\mathrm{s}}\right)$ and lateral anode to cathode distances $\left(\mathrm{d}_{\mathrm{A} \leftrightarrow \mathrm{E}}\right)$ has been proposed in this study.

It was observed that the changing electrode length $\left(l_{\mathrm{e}}\right)$ had a significant effect on the performance of the EK treatment of the soils. The changing electrode lengths $\left(1_{\mathrm{e}}\right)$ altered the plasticity index (PI) and swelling potential (SP) values of the EK treated soils along the soil depths $\left(\mathrm{d}_{\mathrm{s}}\right)$ and the lateral anode to cathode distances $\left(\mathrm{d}_{\mathrm{A} \leftrightarrow \mathrm{E}}\right)$.

The longer electrode length $\left(l_{\mathrm{e}}\right)$ with large surface area contact within the ionic solutions chambers provided a better reduction in the PI and SP values of the EK treated soils.

The efficiency of the changing electrode lengths $\left(1_{\mathrm{e}}\right)$ during the EK treatment was in the order of $1.01_{\mathrm{e}}>0.751_{\mathrm{e}}>$ $0.51_{e}>0.251_{e}$ along with the soil depth $\left(d_{s}\right)$ and lateral anode to cathode distances $\left(\mathrm{d}_{\mathrm{A} \leftrightarrow \mathrm{E}}\right)$ for the PI and the SP values of the EK treated soils. 
The efficiency of EK treatment at different points of soil extraction was in the order of $\mathrm{A} \approx \mathrm{E}>\mathrm{B} \approx \mathrm{D}>\mathrm{C}$ for the $\mathrm{PI}$ values, and $\mathrm{A} \approx \mathrm{E}>\mathrm{C}$ for the $\mathrm{SP}$ values of the $\mathrm{EK}$ treated soils.

In this study, the changing electrode lengths of $0.51_{\mathrm{e}}$ and $0.751_{\mathrm{e}}$ were suitable to improve specific soil depths during the EK treatment of soil.

Statistical equations were developed to estimate the sufficient electrode length $\left(l_{\mathrm{e}}\right)$ suitable for specific soil depths $\left(d_{s}\right)$, and lateral anode to cathode distances for the problematic fine-grained soil used in this study.

The equations showed that the changing electrode length $\left(l_{\mathrm{e}}\right)$ was a significant factor that can be used to navigate design models for large-scale geotechnical in situ applications of EK treatment to improve a wide range of problematic soils.

\section{Compliance with Ethical Standards.}

Conflict of Interest. The authors declare that they have no conflict of interest.

\section{REFERENCES}

Abiodun, A.A. \& Nalbantoğlu, Z. 2016. An Overview of Electrokinetic for Soil Treatment, 4th Intl. Conf. on New Dev. in Soil Mech. and Geotech. Eng., Nicosia, North Cyprus, June.

Abiodun, A.A. \& Nalbantoğlu, Z. 2018. Sacrificial Anode Protection for Electrodes in Electrokinetic Treatment of Soils', In Proceedings of China-Europe Conf. on Geot. Eng., (773-777), Springer, Cham.

Abdullah, W.S. \& Al-Abadi, A.M. 2010. Cationic-electrokinetic improvement of an expansive soil. Applied Clay Science, 47(3):343-350.

Acar, Y.B. \& Alshawabkeh, A.N., 1993. Principles of electrokinetic remediation. Environmental science \& technology, 27(13):2638-2647.

Ahmad, K., Kassim, K.A. \& Taha, M.R. 2006. Electroosmotic flows and electromigrations during electrokinetic processing of tropical residual soil. Malaysian Journal of Civil Engineering, 18(2):74-88.

Alrubaye, A. J., Muzamir, H., \& Fattah, M. Y. 2018. Effects of using silica fume and lime in the treatment of kaolin soft clay, Geomechanics and Engineering, 14(3):247-255.

Anderson, M.J. \& Whitcomb, P.J. 2016. RSM Simplified: Optimizing Processes using Response Surface Methods for Design of Experiments, (2nd Edition), Productivity Press, New York, NY, USA.

Askin, T. \& Turer, D., 2016. Effect of electrode configuration on electrokinetic stabilization of soft clays. Quarterly Journal of Engineering Geology and Hydrogeology, 49(4):322-326.

ASTM D4546-08. 2007. Standard Test Methods for One-Dimensional Swell or Collapse of Soils, ASTM International, West Conshohocken, Pennsylvania, PA, USA.

Azhar, A. T. S., Azim, M. A. M., Syakeera, N. N., Jefferson, I. F. \& Rogers, C. D. F., 2017. Application of Electrokinetic Stabilisation (EKS) Method for Soft Soil: A Review. In IOP Conference Series: Materials Science and Engineering, 226(1):012075. IOP Publishing.

Azhar, A.T.S., Nordin, N.S., Azmi, M.A.M., Embong, Z., Sunar, N., Hazreek, Z.A.M. \& Aziman, M. 2018. The Physical Behavior of Stabilised Soft Clay by Electrokinetic Stabilisation Technology. In Journal of Physics: Conference Series 995(1):012111. IOP Publishing. 
Bezerra, M.A., Santelli, R.E., Oliveira, E.P., Villar, L.S. \& Escaleira, L.A. 2008. Response surface methodology (RSM) as a tool for optimization in analytical chemistry. Talanta, 76(5):965-977.

Cho, J.M., Kim, D.H., Yang, J.S. \& Baek, K. 2012. Electrode configuration for electrokinetic restoration of greenhouse saline soil. Separation Science and Technology, 47(11):16771681.

Croarkin, C., Tobias, P., Filliben, J.J., Hembree, B. \& Guthrie, W. 2006. NIST/SEMATECH E-Handbook of Statistical Methods, NIST/SEMATECH, U.S. Department of Commerce, USA.

Feijoo, J., Ottosen, L. M., Nóvoa, X. R., Rivas, T., \& de Rosario, I. 2017a. An improved electrokinetic method to consolidate porous materials. Materials and Structures, 50(3):186.

Feijoo, J., Nóvoa, X. R. \& Rivas, T. 2017b. Electrokinetic treatment to increase bearing capacity and durability of a granite. Materials and Structures, 50(6):251.

Gingine, V., Shah, R., Venkata Koteswara Rao, P. \& Hari Krishna, P. 2013. A review on study of electrokinetic stabilization of expansive soil, Int. J. Earth Sci Eng., 6(2):176-181.

Jayasekera, S. 2015. Electrokinetics to modify strength characteristics of soft clayey soils: a laboratory based investigation. Electrochimica Acta, 181:39-47.

Jeyakanthan, V., Gnanendran, C.T., and Lo, S.C. 2011. Laboratory assessment of electroosmotic stabilization of soft clay', Canadian Geotechnical Journal, 48(12):788-1802.

Kamani, H., Safari, G.H., Asgari, G. \& Ashrafi, S.D. 2018. Data on modelling of enzymatic elimination of Direct Red 81 using response surface methodology', Data in brief, 18:80-86.

Kaur, G., Rath, G., Heer, H. \& Goyal, A. K. 2012. Optimization of Protocell of Silica Nanoparticles Using 32 Factorial Designs', AAPS PharmSciTech, 13(1):167-173.

Liaki, C., Rogers, C.D.F. \& Boardman, D.I. 2010. Physico-chemical effects on clay due to electromigration using stainless steel electrodes", Journal of applied electrochemistry, 40(6):1225-1237.

Liu, F., Fu, H., Wang, J., Mi, W., Cai, Y. \& Geng, X. 2017. Influence of soluble salt on electro-osmotic consolidation of soft clay. Soil Mechanics and Foundation Engineering, 54(1):49-55.

Liu, Y., Xie, X., Zheng, L., and Li, J. 2018. Electroosmotic Stabilization on Soft Soil: Experimental Studies and Analytical Models (A historical review). International Journal of Electrochemical Science, 13(9):90519068 .

Malekzadeh, M., Lovisa, J. \& Sivakugan, N. 2016. An overview of electrokinetic consolidation of soils. Geotechnical and Geological Engineering, 34(3):759-776.

Malekzadeh, M. \& Sivakugan, N. 2017. One-dimensional electrokinetic stabilization of dredged mud. Marine Georesources and Geotechnology, 35(5):603-609.

Moayedi, H., Nazir, R., Kazemian, S. \& Huat, B. K. 2014a. Microstructure analysis of electrokinetically stabilized peat. Measurement, 48:187-194.

Moayedi, H., Nazir, R., Kassim, K.A. \& Huat, B.K. 2014b. Measurement of the electrokinetic properties of peats treated with chemical solutions. Measurement, 49:289-295.

Mohanty, S.K., Pradhan, P.K. \& Mohanty, C.R. 2017. Stabilization of expansive soil using industrial wastes', Geomechanics and Engineering, 12(1):111-125.

Montgomery, D.C., Runger, G.C. \& Hubele, N.F. 2009. Engineering Statistics, John Wiley \& Sons, USA.

Montgomery, D.C. 2017. Design and Analysis of Experiments. John Wiley \& Sons, New York, NY, USA.

Mosavat, N., Oh, E. \& Chai, G. 2012. A review of electrokinetic treatment technique for improving the engineering characteristics of low permeable problematic soils, Int. J. of Geomate, 2(2):266-272. 
Mosavat, N., Oh, E. \& Chai, G. 2014. Laboratory evaluation of physico-chemical variations in bentonite under electrokinetic enhancement, Int. J. of Geo.: geot., const. mat. and env., 6(1):817-823.

Myers, R.H., Montgomery, D.C. \& Anderson-Cook, C.M. 2009. Response Surface Methodology, John Wiley and Sons, Inc, New Jersey, NJ, USA, 20:38-44.

Mu'azu, N. D., Essa, M. H. \& Lukman, S. 2017. Response Surface Modeling of Rate of Replenishing Processing Fluids During Hybrid Electrokinetics-Adsorption Treatment of Saline-Sodic Soil. Arabian Journal for Science and Engineering, 42(3):1117-1127.

Panjaitan, N. \& Andi, A. 2017. Electrokinetic phenomena of cation exchange and its effect on the behaviour of expansive clays. International Journal, 13(38):173-177.

Peck, R.B., Hanson, W.E. \& Thornburn, T.H. 1974. Foundation engineering, New York Wiley.

Rittirong, A., Shang, J.Q., Mohamedelhassan, E., Ismail, M.A. \& Randolph, M.F. 2008. Effects of electrode configuration on electrokinetic stabilization for caisson anchors in calcareous sand. Journal of Geotechnical and Geoenvironmental Engineering, 134(3):352365.

STAT-EASE. 2011. Design-Expert Reference Manual, STAT-EASE Corporation, Minnesota, USA.

Wang, Q., Hou, Y., Xu, Z., Miao, J., and Li, G. 2008. “'Optimization of cold-active protease production by the psychrophilic bacterium Colwellia sp. NJ341 with response surface methodology”, Bioresource technology, 99(6):1926-1931.

Wu, H., Hu, L., and Zhang, G. 2016. Effects of electro-osmosis on the physical and chemical properties of bentonite. Journal of Materials in Civil Engineering, 28(8):06016010. 